\title{
Sulfide, microcystin, and the etiology of black band disease
}

\author{
Laurie L. Richardson ${ }^{1, *}$, Aaron W. Miller ${ }^{1}$, Emily Broderick ${ }^{1}$, Longin Kaczmarsky ${ }^{1}$, \\ Miroslav Gantar ${ }^{1}$, Dina Stanić ${ }^{1}$, Raju Sekar ${ }^{1,2}$ \\ ${ }^{1}$ Department of Biological Sciences, Florida International University, Miami, Florida 33199, USA \\ ${ }^{2}$ Present address: Biological and Environmental Systems Group, Department of Chemical and Process Engineering, \\ The University of Sheffield, Sheffield S1 3JD, UK
}

\begin{abstract}
Black band disease (BBD) consists of a cyanobacterial-dominated, sulfide-rich microbial mat that migrates across coral colonies, degrading coral tissue. The mat contains diverse bacteria that include photoautotrophs (cyanobacteria), sulfate-reducers, sulfide-oxidizers, and organoheterotrophs. BBD sulfate-reducers contribute to BBD pathobiology by production of sulfide, which causes coral tissue lysis and death, and the cyanotoxin microcystin is produced by BBD cyanobacteria. Here we used a model system of coral fragments to investigate the roles of sulfide and microcystin in BBD by exposure to the metabolic inhibitors sodium molybdate and 3-(3', 4'-dichlorophenyl)-1,1-dimethylurea (DCMU), which inhibit sulfate reduction and oxygenic photosynthesis, respectively. Exposure of BBD inocula to sodium molybdate prior to inoculation prevented infection of healthy fragments but did not prevent continued band migration and coral tissue lysis by active BBD infections. Exposure to DCMU did not inhibit either the initiation of BBD or continued migration of active BBD. Exposure of healthy coral fragments to sulfide, purified microcystin, and a combination of both revealed that both microcystin and sulfide are toxic to coral and act synergistically. Measurement of growth of bacteria isolated from BBD and the healthy coral surface mucopolysaccharide layer (SML) during exposure to microcystin revealed that growth of relatively more BBD than SML isolates was stimulated, although effects were not uniform and the majority exhibited no effect. Our results indicate that sulfide is required for initiation of $\mathrm{BBD}$, both microcystin and sulfide are involved in BBD pathobiology, and microcystin may structure the BBD bacterial community.
\end{abstract}

KEY WORDS: Black band disease $\cdot$ Coral disease $\cdot$ Polymicrobial disease $\cdot$ Microcystin $\cdot$ Sulfide

\section{INTRODUCTION}

Black band disease (BBD) is among the most widespread and destructive of coral diseases. Since its first record in the 1970s on reefs of the wider Caribbean (Antonius 1973), it has spread to the Red Sea, the IndoPacific, and the Great Barrier Reef (Antonius 1985, 1988, Dinsdale 2002). Although BBD prevalence is typically low $(<1 \%)$ compared to other coral diseases, it is considered to be a serious coral disease due to the fact that it targets slow-growing reef-framework scleractinian coral species that cannot outgrow the migrating, tissue-lysing band (Richardson 2004).
Studies of the epizootiology of BBD have focused on its effects on coral reef host populations (Edmunds 1991, Kuta \& Richardson 1996, Bruckner \& Bruckner 1997, Dinsdale 2002) as well as the relationship between disease dynamics and environmental factors such as nutrients and temperature (Kuta \& Richardson 2002, Kaczmarsky et al. 2005, Rodriguez \& Croquer 2008). Additionally, many studies have described BBDassociated microorganisms using both microscopic (Garrett \& Ducklow 1975, Ducklow \& Mitchell 1979, Rützler \& Santavy 1983, Rützler et al. 1983) and molecular (Cooney et al. 2002, Frias-Lopez et al. 2004, Sekar et al. 2006, 2008) approaches. To date, the cumulative 
results of these studies suggest that BBD is a polymicrobial disease and that disease etiology is based on diverse members of 4 BBD physiological functional groups: photoautotrophs (cyanobacteria), sulfatereducers, sulfide-oxidizers, and organoheterotrophs (Richardson 2004). Studies of BBD using molecular community profiling techniques have suggested that the specific members of each of these 4 groups are highly variable across geographic region and host coral species (Cooney et al. 2002, Frias-Lopez et al. 2004, Myers et al. 2007, Sekar et al. 2008).

Relatively little work has documented the specific toxins or toxicants involved in scleractinian coral disease pathobiology. It is known that a toxic peptide is involved in bacteria-induced coral bleaching by Vibrio shilonii (Banin et al. 2001), and an extracellular factor causes tissue lysis associated with 'white plague-like' disease of corals (Barash et al. 2005). We have been working on identifying the toxins and toxicants associated with BBD. Three of the 4 major BBD physiological groups are associated with production of harmful compounds. The sulfide produced by BBD (and other) sulfate reducers is toxic to eukaryotes in general (Vismann 1991) and causes tissue lysis and coral death in corals exposed to concentrations measured in intact BBD infections using sulfide-sensitive microelectrodes (Carlton \& Richardson 1995, Richardson et al. 1997). We have recently determined that the cyanotoxin microcystin is present in BBD and produced in cultures of cyanobacteria isolated from BBD (Richardson et al. 2007). Microcystin, a potent toxin that affects cellular processes, e.g. by inhibition of protein phosphatase (Sim \& Mudge 1993) and induction of apoptosis (Hooser 2000), is potentially active in coral tissue death. While we have not documented or measured toxins produced by BBD organoheterotrophic bacteria, we have repeatedly detected sequences most closely homologous to bacteria associated with toxic dinoflagellates in our studies of BBD bacterial communities using cloning and sequencing of the 16S rRNA gene (Sekar et al. 2006, 2008).

Here we present results of experiments in which we used metabolic inhibitors to disrupt the major energy yielding metabolic pathways associated with 2 of the 4 major BBD bacterial physiological groups, oxygenic photosynthesis of BBD cyanobacteria and sulfate reduction of $\mathrm{BBD}$ sulfate reducers, to assess the contribution of these metabolic processes to BBD infection in corals. We additionally performed experiments in which healthy coral fragments were exposed to sulfide, microcystin, and a combination of the two, with the effects assessed using scanning electron microscopy (SEM) to investigate the effects of these $2 \mathrm{BBD}$-associated toxic compounds in BBD pathobiology. Finally, we assessed the effect of microcystin exposure on growth of bacteria isolated from BBD and the surface mucopolysaccharide layer (SML) of healthy coral colonies to determine a potential role of this compound in the composition of BBD microbial communities.

\section{MATERIALS AND METHODS}

Collection of coral fragments and black band inocula. Coral fragments were collected while SCUBA diving on reefs of Lee Stocking Island (LSI), Bahamas, for use in metabolic inhibition experiments, and from reefs of the Florida Keys for microcystin and sulfide exposure experiments. All coral fragments were from the reef-framework species Montastraea annularis and consisted of 'skirt fragments.' This term refers to the edges of colonies (the 'skirt') that were chipped off using a chisel and hammer. Skirt fragments were approximately 3 to $5 \mathrm{~cm}$ by 3 to $4 \mathrm{~cm}$. After collection, fragments were placed immediately into plastic bags (underwater) with ample seawater to allow the fragments to be suspended. For transport to the laboratory, the bags were floated in a cooler with ambient temperature seawater.

Fresh BBD for inocula was collected from infected colonies of 3 coral species (Montastraea annularis, Siderastrea siderea, and Colpophyllia natans) on reefs of LSI using sterile 10 or $60 \mathrm{ml}$ syringes by aspirating the band from the coral surface. After collection, syringes were maintained at ambient temperature (floated in freshly collected seawater in a cooler) until return to the laboratory. Once at the laboratory, BBD samples were placed in $125 \mathrm{ml}$ Erlenmeyer flasks with approximately $100 \mathrm{ml}$ of fresh seawater and placed in experimental flumes (see next section). BBD samples were maintained overnight prior to use for infection the next morning. Experimental infections were conducted over 2 time periods in 2004 (8 to 12 August) and 2005 (11 to 15 July) to ensure that each experiment, which contained varying replicates (minimum of 3 per treatment), was repeated 3 times. In each experiment, $M$. annularis fragments were infected.

The use of fragments from only 1 (Montastraea annularis) of the 3 coral hosts from which BBD inocula were obtained for use in these experiments was based on 2 issues. First, $M$. annularis can be sampled relatively non-destructively by chipping skirt fragments off of the colony base with a great deal of control of the fragment size and little damage to the colony. Alternatively, obtaining fragments from Siderastrea siderea or Colpophyllia natans involves chiseling out large fragments with much damage to the host (the first being very hard and dense, the second friable and fragile), which are then difficult to subsample to comparable 
sizes for experimentation. Second, since this research was targeted at examining sulfide and microcystin in BBD, our sampling strategy was supported by the fact that we have directly measured sulfide in BBD on both M. annularis and C. natans (e.g. Carlton \& Richardson 1995) and have observed sulfide-oxidizers in BBD from all coral host species examined, including from $S$. siderea. Furthermore, we have directly measured microcystin in BBD from all 3 coral hosts (Richardson et al. 2007). Therefore, we believe the 2 toxins were active in all inocula. Thus, once a band had formed (successful inoculation), we believe that these 2 substances were present.

Metabolic inhibition experiments. Metabolic inhibition experiments were conducted in the wet laboratory facilities at the Perry Institute for Marine Sciences, LSI, Bahamas. This facility contains flumes supplied with sand-filtered $(2 \times)$ seawater. The flumes are housed in a greenhouse-type room with double-layer screening that acts as a neutral density filter.

Experimental chambers, consisting of $750 \mathrm{ml}$ plastic containers, were placed in the flumes. For acclimation (pre-experiment) and control coral fragments, seawater continually flowed into each experimental chamber via a PVC pipe system. Each chamber had an outflow, and the chambers themselves sat in approximately $6 \mathrm{~cm}$ of water in the flumes to maintain temperature at ambient (reef) levels.

Experimental coral fragments were placed, after acclimation and recovery from sampling, in 11 glass beakers placed in the experimental chambers. The beakers were raised above the chamber floor such that the overflow level of the chamber was slightly below the rim of the beaker. The inhibitors 3-(3', 4'-dichlorophenyl)-1,1-dimethylurea (DCMU) and sodium molybdate were added to the beakers, which contained experimental coral fragments. Temperature and light were the same as the control fragments in the chambers. Because there was no flow through of water in the experimental beakers (to prevent flushing of the inhibitors) each beaker was aerated near the surface using tubing attached to an air pump. The tubing was placed such that air bubbles would swirl around the circumference of the beaker with no direct bubbling onto the experimental corals.

To inoculate coral fragments, a 3 to $4 \mathrm{~mm}$ diameter piece of BBD mat was collected using a Pasteur pipette. The clump was carefully placed near the edge of each experimental fragment on the surface of healthy coral tissue and monitored visually. During the first 20 to $30 \mathrm{~min}$, the aerator tubing was removed from the experimental beakers to prevent the inoculum clump from being dislodged from the coral surface by water movement. During this time period, the coral would at times push the clump off of the coral surface, presumably via mucus extrusion. When this happened, the clump was retrieved using a Pasteur pipette and redeposited onto the coral fragment. In a few cases, the coral repeatedly removed the BBD inoculum; in these cases, the tip of a Pasteur pipette was positioned to rest on the clump to hold it onto the colony. In all cases it was visually apparent when the clump had firmly attached to the coral surface (the first step of infection).

For inhibition experiments, the inhibitor DCMU, which inhibits oxygenic photosynthesis, was prepared to a final concentration of $5 \mu \mathrm{M}$ from a $10^{-4} \mathrm{M}$ stock solution made using sterile seawater. To inhibit sulfate reduction, sodium molybdate was used at a final concentration of $2 \mathrm{mM}$, prepared using a stock solution $(0.2 \mathrm{M})$ in sterile seawater.

To confirm that the inhibitor DCMU was penetrating the band and shutting off Photosystem II, an oxygensensitive, needle-encased mini-electrode (Diamond General, model 760) attached to a picoammeter (Diamond General Chemical Microsensor, model 1201) was used to measure photosynthetic oxygen evolution in BBD on fragments with and without DCMU. The mini-electrode was calibrated by alternately inserting the tip just below the interface of seawater and air $\left(21 \% \mathrm{O}_{2}\right)$ and inserting the tip in the center of a $1 \mathrm{~cm}^{3}$ clump of $\mathrm{BBD}\left(\% \mathrm{O}_{2}\right)$ until readings were stable. The inside of a BBD clump is anaerobic as determined in previous studies using oxygen-sensitive electrodes (Carlton \& Richardson 1995). This 2 point calibration method is based on the linear response of this type of electrode. It was determined that the DCMU was working by measuring the absence of oxygen at and near the surface of the band compared to the oxygenated band with no DCMU.

To verify that the sodium molybdate was inhibiting sulfate reduction, clumps of BBD were exposed to this inhibitor overnight and then examined microscopically. At a concentration of $1 \mathrm{mM}$, eukaryotes (diatoms and filamentous green algae) were observed to be present in the BBD consortium, suggesting alleviation of sulfide toxicity and thus indicating that the inhibitor was working. However, some filamentous sulfideoxidizers were also present. The concentration was increased to $2 \mathrm{mM}$, after which no sulfide-oxidizers were observed. This concentration was used in experiments, with microscope checks of experimental bands conducted to confirm the lack of sulfide-oxidizers (thus the lack of sulfide).

Two sets of inhibition experiments were conducted. In the first, the BBD inoculum was exposed overnight to the inhibitors prior to inoculation of healthy coral fragments. In these experiments, inhibitors were also added to the experimental beakers immediately after inoculation. In the second set of experiments, fragments were inoculated with $\mathrm{BBD}$ and the inhibitors 
were added to experimental beakers only after the band had formed and was actively migrating across the coral. Control beakers had only seawater. For each experiment, migration and tissue lysis by BBD were observed and recorded, and documented by photographing the coral fragments.

Microcystin and sulfide exposure experiments. To assess the effects of microcystin and sulfide on corals, fragments of Montastraea annularis collected from the Florida Keys were exposed (after acclimation in laboratory aquaria) to these substances under controlled conditions in the laboratory. Exposure experiments were performed at Florida International University (FIU) using plexiglass chambers constructed such that the interior could be stirred with a magnetic stirrer without disrupting the coral fragment (see next paragraph). Each chamber (volume $=150 \mathrm{ml}$ ) was first filled with $125 \mathrm{ml}$ of artificial seawater (ASW). For microcystin exposure experiments, microcystin was added from a stock solution (100 $\left.\mathrm{mg} \mathrm{l}^{-1}\right)$ of purified microcystin-LR (MC-LR obtained from K. Rein, FIU) to final concentrations of $1 \mu \mathrm{g} \mathrm{l}^{-1}, 50 \mu \mathrm{g} \mathrm{l}^{-1}$, or $100 \mu \mathrm{g} \mathrm{l}^{-1}$. For sulfide exposure experiments, chambers containing ASW (with microcystin when appropriate) were first bubbled (in a hood) with $100 \%$ reagent-grade $\mathrm{N}_{2}$ gas for 20 min and capped with a rubber stopper. To add sulfide, the stopper was carefully lifted, and the sulfide was added using a syringe under a stream of $\mathrm{N}_{2}$ gas. Sulfide was added from a stock solution of $0.1 \mathrm{M}$ $\mathrm{Na}_{2} \mathrm{~S} \cdot 9 \mathrm{H}_{2} \mathrm{O}$ to a final concentration of $0.5 \mathrm{mM}$.

In these experiments a small coral fragment (approximately $1 \mathrm{~cm}^{2}$ ) was placed on a stand in the center of the chamber and held in place with a small piece of modeling clay. The stand was elevated to allow the presence of a stirbar at the base of the chamber. In each experiment, one fragment was maintained as a control (no microcystin or sulfide was added). Experimental conditions (with duplicate fragments for each condition in each experiment) were as follows: MC-LR at 1, 50, and $100 \mathrm{\mu g} \mathrm{l}^{-1}$ (no sulfide); $50 \mu \mathrm{g} \mathrm{l}^{-1}$ microcystin plus $0.5 \mathrm{mM}$ sulfide; $100 \mu \mathrm{g} \mathrm{l}^{-1}$ microcystin plus $0.5 \mathrm{mM}$ sulfide; and $0.5 \mathrm{mM}$ sulfide (no microcystin). Thus each of the 3 replicated experiments used 13 coral fragments (1 control plus duplicates of each treatment) for a total of 36 fragments investigated. In all experiments using sulfide (source as described above), the coral fragment was mounted on the stand in the chamber under a stream of $\mathrm{N}_{2}$ gas and immediately capped with a rubber stopper prior to introduction of sulfide, which was then introduced as above. Controls were not kept under nitrogen (used to prevent oxidation of the sulfide) since oxygen evolution by coral-associated zooxanthellae continued for the controls. This was not the case for the experimental fragments since sulfide blocks Photosystem II (thus oxygen evolution) in photosynthetic eukaryotes (Vismann 1991).

Experimental chambers were maintained at $30^{\circ} \mathrm{C}$ in a $15 \mathrm{l}$ aquarium with each chamber positioned above a magnetic stirrer. Light was maintained at $246 \pm 9.6 \mu \mathrm{E}$ $\mathrm{m}^{2} \mathrm{~s}^{-1}$. Experiments (each conducted in duplicate except for the control) were repeated for a total of 3 times. Incubations (exposure to microcystin and/or sulfide) ranged from 18 to $22.5 \mathrm{~h}$ before harvesting for SEM, at which time fragments were removed from the chambers and photographed on a Leica Mz6 dissecting scope with a Leica DC 500 digital camera system.

SEM. In preparation for viewing with SEM, harvested fragments were fixed in a solution of $2 \%$ gluteraldehyde in $0.05 \mathrm{M}$ sodium cacodylate buffered seawater fixative and maintained at $4^{\circ} \mathrm{C}$ until processing. To process samples, fragments were placed in $0.05 \mathrm{M}$ sodium cacodylate buffer made with filtered seawater (three changes at $10 \mathrm{~min}$ each), and post-fixed in $1 \%$ osmium tetroxide for $45 \mathrm{~min}$ (added directly to the buffer). Fragments were partially decalcified in a solution of $22 \%$ formic acid buffered with $10 \%$ sodium citrate, after which they went through another series of 3 changes of cacodylate buffer (10 min each). Samples were then dehydrated through a series of graded ethanol by placing them in 3 washes of each concentration of $20,40,60,70,90$, and $100 \%$ ethanol (10 min for each wash). This was followed by further dehydration (3 changes at 10 min each) using hexamethyldisilazane (HMDS) with out-gassing overnight. Fragments were affixed to an aluminum stub using carbon adhesive tape, and were coated in a thin layer of palladium using a sputter coater (Cressington 108 Sputtercoater, Cressington Scientific). Fragments were viewed using a Philips XL30 ESEM-FEG located at the University of Miami Center for Advanced Microscopy.

Effect of microcystin on bacterial growth. Bacteria used in this study were isolated from BBD on infected colonies, and the SML of apparently healthy colonies, of Siderastrea siderea on reefs of the Florida Keys (SML) and Lee Stocking Island, Bahamas (BBD). Additionally, cultures of the known coral pathogens Aurantimonas coralicida, Vibrio shilonii, and Serratia marcescens were tested.

To obtain isolates, the black band mat or the SML were sampled using sterile needleless $10 \mathrm{ml}$ syringes. Samples were placed in cryovials, maintained at ambient (seawater) temperature, and upon return to the lab plated onto Difco marine agar 2216. After incubation at room temperature, colonies with different morphologies were picked and replated to purity. Cultures were maintained at room temperature on marine agar slants. For this study, 10 isolates from BBD, 12 from the SML of apparently healthy corals, and 3 known coral pathogens were used. BBD isolates were cloned and 
sequenced, with sequences BLAST-searched in GenBank for identification, as described by Sekar et al. (2006), with the exception that the SML isolates were sequenced using only the forward primer (27F). Thus, while the 16S rRNA genes from the BBD isolates were fully sequenced (both $27 \mathrm{~F}$ and 1492R primers), this gene from the SML isolates was only partially sequenced (586 to $672 \mathrm{bp}$ ).

Prior to the microcystin exposure experiments, each isolate was first grown in marine broth for $2 \mathrm{~d}$. For each experiment 3 different concentrations (1, 100, and $500 \mu \mathrm{g} \mathrm{l}^{-1}$ ) of MC-LR were used for each isolate with assays conducted in triplicate in plastic 96-well microplates. For each treatment, $20 \mu \mathrm{l}$ of MC-LR (dissolved in methanol at the appropriate concentration) were added to experimental wells and placed under a sterile hood to evaporate the solvent. The control wells did not contain microcystin. After evaporation, $190 \mu \mathrm{l}$ of marine broth (Difco) were added to all wells. To start the experiment, $10 \mu \mathrm{l}$ of each bacterial culture were added to all control and experimental wells (each in triplicate), and incubated at $26^{\circ} \mathrm{C}$ overnight for $12 \mathrm{~h}$. Control and experimental wells were inoculated from the same culture at the same time.

Bacterial growth was quantified by measuring optical densities in the 96-well plates, after the exposure/ incubation period, by using a microplate reader (BioTek, model Synergy2) at a wavelength of $405 \mathrm{~nm}$. The effects of the different concentrations of microcystin on bacterial growth were quantified by calculating the average optical density at the end of each experiment in both the triplicate control and experimental wells (also triplicate for each concentration of microcystin). The control and experimental wells were then statistically compared by a 2-sample $t$-test assuming equal variances with an alpha value of 0.05

\section{RESULTS}

\section{Metabolic inhibition experiments}

The model used in this study is shown in Fig. 1. Inoculation (Fig. 1A) was always performed near the edge of a healed fragment. The coral was not wounded prior to infection. Such inoculation resulted in formation of a band within $1 \mathrm{~d}$, which then actively migrated across the fragment, lysing coral tissue similar to naturally occurring $\mathrm{BBD}$ infections observed in the field (Fig. 1B-D). Montastraea annularis was readily infected with inocula using BBD from the hosts $M$. annularis and Siderastrea siderea, but not from Colpophyllia natans. When BBD from C. natans was used, after a minimum of $3 \mathrm{~d}$ the inoculum would at times attach to the coral surface, but never formed a migrating band. Therefore, experiments were conducted using only BBD inocula from $M$. annularis and $S$. siderea.

To assess the effect of the inhibitors DCMU and sodium molybdate on BBD infection, BBD inocula were exposed to each inhibitor overnight with infection
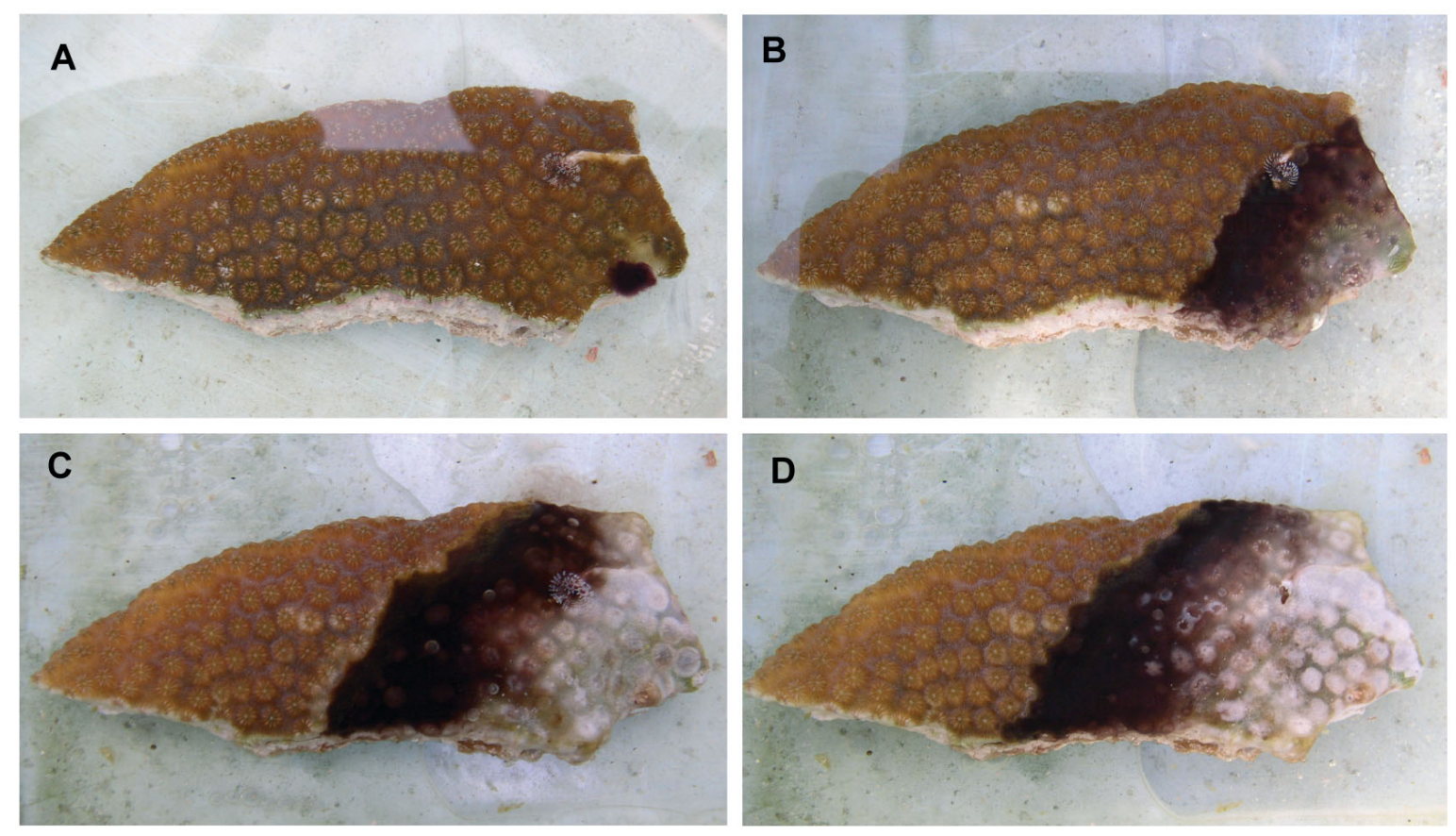

Fig. 1. Black band infection model. The coral fragment is from the host Montastraea annularis. (A) $t$ (time) $=0$ (immediately after inoculation). (B) $t=3 \mathrm{~d}$. (C) $t=7 \mathrm{~d}$. (D) $t=8 \mathrm{~d}$ 
implemented the following morning. Fig. 2A-D shows the results of 1 representative experiment. In all cases ( $n=3$ experiments, minimum of 3 replicates per experiment) DCMU failed to prevent infection. As seen in Fig. 2C, a band formed similar to the control and progressed across the coral fragment, lysing tissue. In contrast, exposure to sodium molybdate prevented BBD infection in all cases attempted (Fig. 2D). These results indicate that sulfate reduction is required to initiate BBD from a freshly collected BBD microbial mat. These results also indicate that oxygenic photosynthesis is not required for infection.

The second set of experiments involved exposure of coral fragments with actively migrating BBD to the 2 inhibitors. As seen in Fig. 2E (DCMU) and F (sodium molybdate), the migrating bands continued to migrate in the presence of both inhibitors. These results show that disrupting sulfate reduction or oxygenic photosynthesis had no effect on active BBD disease. Therefore, as opposed to BBD infection, sulfate reduction was not required to sustain existing $B B D$.

In all cases of each of the above experiments, the control fragments infected with BBD (no inhibitors) produced a band that migrated across the coral fragment, and the control fragments with no BBD and no inhibitors remained healthy (not shown).

\section{Effects of microcystin and sulfide exposure on coral tissue}

Table 1 summarizes the effects of exposure to microcystin on the coral tissue, zooxanthellae, and bacterial community of experimental coral fragments. When examined visually, fragments exposed to increasing microcystin concentrations $\left(1,50\right.$, and $100 \mu \mathrm{g} \mathrm{l}^{-1}$ ) exhibited corresponding decreases in coral surface topography. This effect was also seen with exposure to
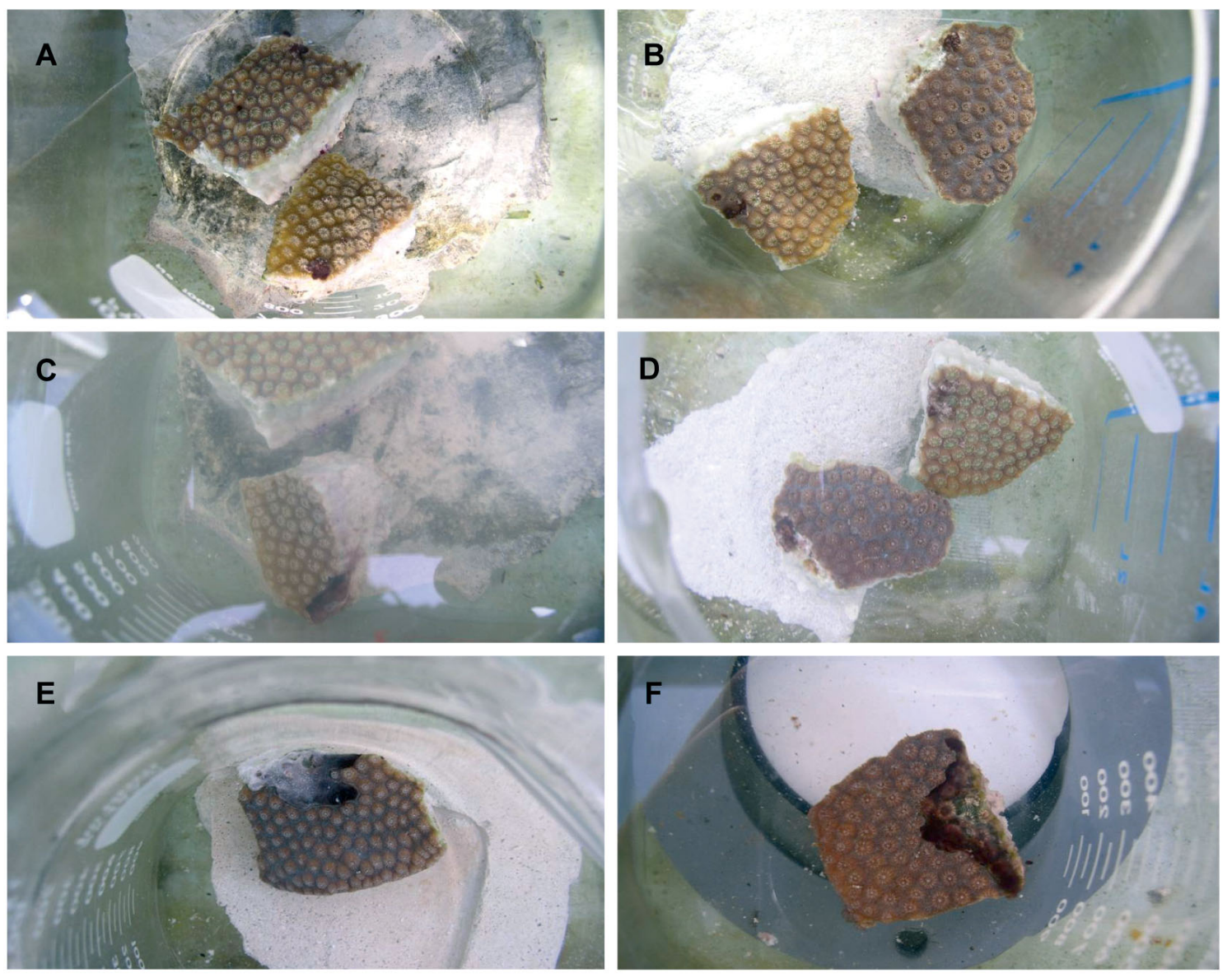

Fig. 2. Effect of the inhibitors DCMU and sodium molybdate on (A-D) black band infection and on (E,F) an actively progressing disease band. Coral fragments are from the host Montastraea annularis. In (A) and (B), the fragments were inoculated with black band disease (BBD) exposed (prior to inoculation) to (A) DCMU and (B) sodium molybdate, both at time $(t)=0$. $(C, D)$ Same fragments at $t=31 \mathrm{~h}$. (E,F) Fragments that had been successfully inoculated with BBD (bands had formed and were actively migrating) and then exposed to (E) DCMU and (F) sodium molybdate. Both panels are at $t=3 \mathrm{~d}$. The white material on the surface of the mat in (E) is the population of the sulfide-oxidizer Beggiatoa, which has risen to the mat surface following the oxygen/sulfide interface. Note: for comparison of fragments, polyps are $3 \mathrm{~mm}$ in diameter 
Table 1. Montastraea annularis. Effect of exposure of apparently healthy coral fragments to purified microcystin-LR (MC-LR) and sulfide. Exposure period ranged from 18 to 22.5 h. Representative scanning electron micrographs shown in Fig. 3

\begin{tabular}{|c|c|c|c|}
\hline $\begin{array}{l}\text { Exposure to MC-LR } \\
\text { and/or sulfide }\end{array}$ & Bacterial growth & Coral tissue & Zooxanthellae \\
\hline Control & Very low & $\begin{array}{l}\text { Healthy and intact } \\
\text { epidermis and gastrodermis }\end{array}$ & Healthy, in gastrodermis \\
\hline $1 \mu g \mathrm{l}^{-1} \mathrm{MC}-\mathrm{LR}$ & High & $\begin{array}{l}\text { Epidermis thinned or absent, } \\
\text { gastrodermis degraded }\end{array}$ & $\begin{array}{l}\text { Healthy, in clusters within gastrodermis or } \\
\text { on surface }\end{array}$ \\
\hline $50 \mu \mathrm{gl}^{-1} \mathrm{MC}-\mathrm{LR}$ & Low & $\begin{array}{l}\text { Epidermis vacuolated, } \\
\text { degraded gastrodermis }\end{array}$ & Healthy, in clusters within gastrodermis \\
\hline $100 \mu \mathrm{g} \mathrm{l}^{-1} \mathrm{MC}-\mathrm{LR}$ & Low & $\begin{array}{l}\text { Epidermis thinned or absent, } \\
\text { degraded gastrodermis }\end{array}$ & $\begin{array}{l}\text { Some degradation, in clusters within } \\
\text { gastrodermis or on surface }\end{array}$ \\
\hline $\begin{array}{l}50 \mu g \mathrm{I}^{-1} \mathrm{MC}-\mathrm{LR} \\
0.5 \mathrm{mM} \text { sulfide }\end{array}$ & Low & $\begin{array}{l}\text { Epidermis thinned or } \\
\text { vacuolated, degraded } \\
\text { gastrodermis }\end{array}$ & $\begin{array}{l}\text { Some degradation, extruded from } \\
\text { gastrodermis }\end{array}$ \\
\hline $\begin{array}{l}100 \mu \mathrm{g} \mathrm{l}^{-1} \mathrm{MC}-\mathrm{LR} \\
0.5 \mathrm{mM} \text { sulfide }\end{array}$ & Low & $\begin{array}{l}\text { Epidermis and gastrodermis } \\
\text { thinned or absent }\end{array}$ & Large clusters on surface, some degradation \\
\hline $0.5 \mathrm{mM}$ sulfide & $\begin{array}{l}\text { Cyanobacterial } \\
\text { filaments present }\end{array}$ & $\begin{array}{l}\text { Epidermis vacuolated or } \\
\text { thinned, gastrodermis } \\
\text { degraded }\end{array}$ & $\begin{array}{l}\text { Appear healthy, in clusters within } \\
\text { gastrodermis }\end{array}$ \\
\hline
\end{tabular}

sulfide. When both compounds were present, the effect was exacerbated. When the fragments were examined using SEM, pronounced effects were apparent. Control fragments (an example is shown in Fig. 3A) contained apparently healthy, intact zooxanthellae that were located in their normal position in the gastrodermis. The epidermis displayed normal columnar cells, with little damage, and normal mucocytes. In contrast, fragments that were exposed to microcystin exhibited a loss of structural integrity in both the epidermis and gastrodermis (Fig. 3B). These fragments also exhibited extrusion of zooxanthellae from the gastrodermis, or formation of clusters of zooxanthellae, but the zooxanthellae generally appeared to be healthy. Columnar cells in the epidermis of microcystin-exposed coral tissues were vacuolated, and there was an absence of mucocytes. In many cases, the epidermis was drastically thinned or absent.

Coral fragments exposed to sulfide exhibited effects similar to those exposed to microcystin, with a loss of organized structure in the tissue layers and zooxanthellae that appeared either to be floating freely in the gastrodermis or to be present as clusters extruded from the gastrodermis (Fig. 3C). Again, the zooxanthellae appeared normal. With sulfide exposure, cyanobacteria were present at the base of the coral tissue (not shown).

The effects of exposure to microcystin or sulfide were exacerbated when the 2 substances were combined (Fig. 3D). In this case, there was vacuolation of the epidermis, severe loss of structure of the columnar cells of the epidermis (when present), and little to no gastrodermis. With combined exposure, the zooxanthellae exhibited some degradation.

Effect of microcystin exposure on bacterial growth

In the experiments described above, it was noted that exposure of coral fragments to $1 \mu \mathrm{g} \mathrm{l}^{-1}$ microcystin was accompanied by an increase in the number of bacteria observable in the coral tissue and on the surface of the zooxanthellae (not shown). At the increased microcystin concentrations, bacteria were still present, but at much lower densities; however, they were more prevalent than in the control (Fig. 3).

Based on these observations, the effect of exposure on the growth of bacteria isolated from BBD and SML was examined. These results are summarized in Table 2. Of the 22 bacterial isolates from BBD (10) or coral SML (12), 9 exhibited a significant response (change in growth relative to the control) when exposed to MC-LR for $12 \mathrm{~h}$ (Table 2). Three of the BBD isolates (strains BBD-2164a, BBD-2164i, and BBD-2171c) were stimulated by microcystin and 1 was inhibited (BBD-2172d). The isolates whose growth was stimulated exhibited this effect when exposed to microcystin concentrations of 1, 100, and $500 \mu \mathrm{g}^{-1}$, but exhibited the effect only at 1 of the 3 concentrations to which they were exposed (see Table 2). The 1 BBD isolate that exhibited growth inhibition did so at a concentration of $100 \mu \mathrm{g} \mathrm{l}^{-1}$ of microcystin; the other 2 concentrations had no effect. In contrast, 3 of the SML isolates (strains H-1-2, H-1-3, and H-1-7) exhibited 

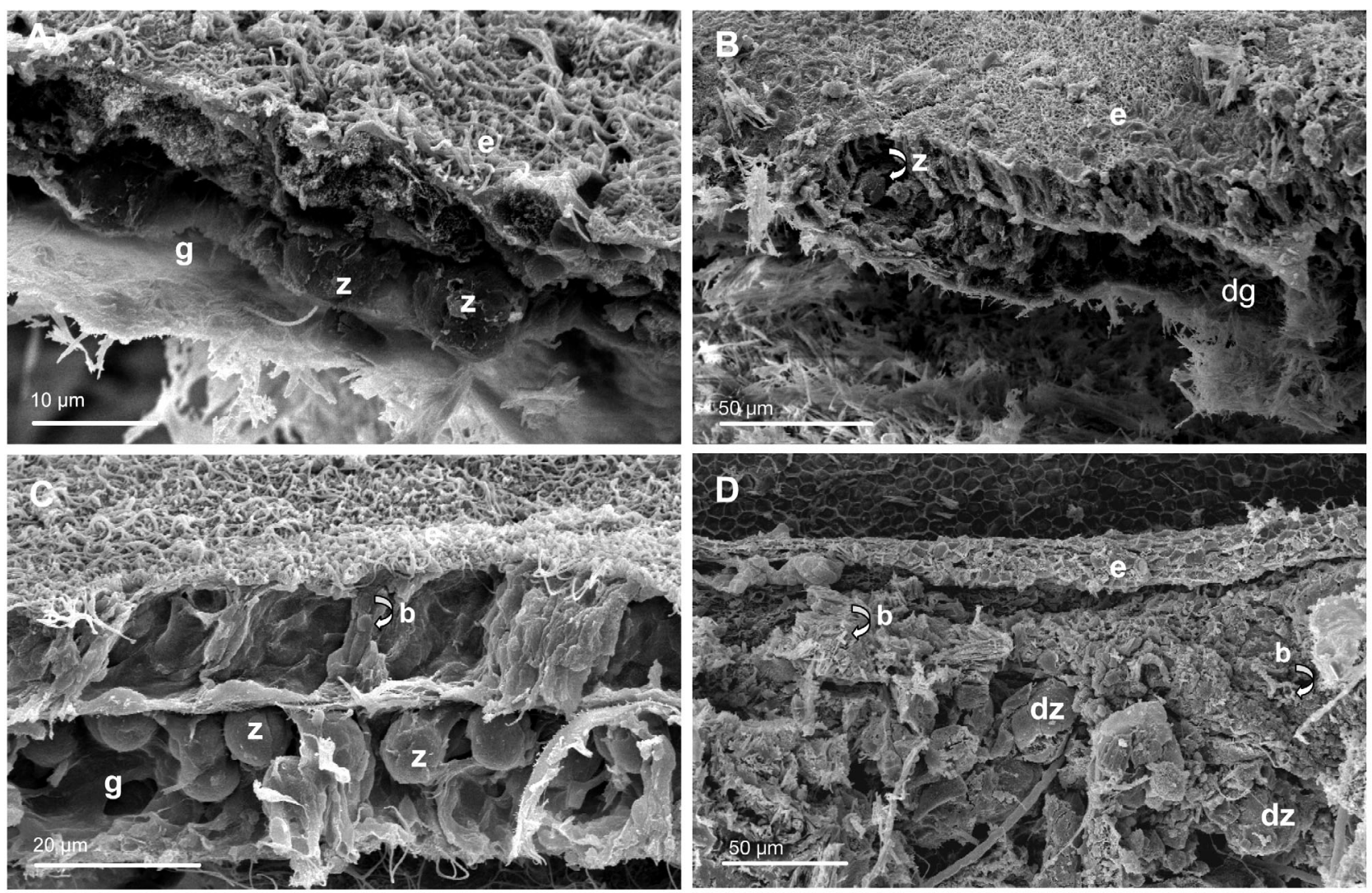

Fig. 3. Montastraea annularis. Scanning electron micrographs of fragments exposed to (B) $50 \mu \mathrm{g} \mathrm{l}^{-1} \mathrm{microcystin}-\mathrm{LR}$, (C) $0.5 \mathrm{mM}$ sulfide, or (D) $50 \mu \mathrm{g} \mathrm{l}^{-1}$ microcystin-LR plus $0.5 \mathrm{mM}$ sulfide. (A) is a control. Note different scale bars on panels. e: epidermis, g: gastrodermis, z: zooxanthella, d: degraded, b: bacteria

growth inhibition at 1 or $500 \mu \mathrm{g} \mathrm{l}^{-1}$, with no effect at other concentrations (see Table 2). Two of the SML isolates (H1-8b and H-1-16) exhibited inhibition at the lowest microcystin concentration $\left(1 \mathrm{\mu g} \mathrm{l}^{-1}\right)$ and stimulation at the higher concentrations. Two of the $10 \mathrm{BBD}$ isolates and 9 of the 12 SML isolates were identified as vibrios. These were variably affected by microcystin ( 3 inhibited, 1 both inhibited and stimulated, and 7 not affected; see Table 2). Of the known coral pathogens, growth of both Vibrio shilonii and Serratia marcescens were stimulated, while that of Aurantimonas coralicida was not affected.

\section{DISCUSSION}

\section{Infection of Montasraea annularis using BBD from different host species}

The work presented here was carried out using fragments of Montasraea annularis as our model organism, selected based on criteria discussed previously. However, there was only one $M$. annularis colony infected with BBD on the reefs of LSI during our field work in 2004 and none in 2005. Additionally, the field trip in
2004 was terminated prematurely due to mandatory evacuation of the field station because a hurricane (Charley) was approaching. To complete a robust data set (3 replicates of each experiment) we returned in 2005, and during this time, the only coral species infected with BBD was Siderastrea siderea.

Experiments conducted in 2004 revealed that infection of Montastraea annularis fragments using BBD from both $M$. annularis and Siderastrea siderea occurred within $3 \mathrm{~h}$, with the initial attachment to the coral surface observable within $20 \mathrm{~min}$. After infection, band progression and tissue lysis proceeded at similar rates, and responses to inhibitors were identical. In contrast, BBD from Colpophyllia natans would not infect our $M$. annularis model. Since it is known that sulfide and microcystin are present in BBD from both coral hosts (Carlton \& Richardson 1995, Richardson et al. 2007), the failure to infect must be based on another factor. It is known that BBD communities are variable over time, across geographic regions, and between coral hosts (Voss et al. 2007), and that different coral hosts have different, and specific, SML bacterial communities (Rohwer et al. 2002). However, very little is known about the relationships between these 2 (BBD 
Table 2. Effect of microcystin on growth of bacterial isolates from black band disease (BBD) and coral surface mucopolysaccharide layer (SML). Purified microcystin (MC-LR) was used at 3 concentrations $\left(1,100\right.$, and $500 \mathrm{\mu g}^{-1}$ ). Growth was compared to that of controls (no microcystin) for each isolate for each experiment ( $\mathrm{n}=3$ experiments, each with triplicate incubations). Response designated as S: stimulation, I: inhibition, -: no effect. na: not applicable. $\mathrm{p}$ values based on 2 sample $t$-test, assuming equal variances

\begin{tabular}{|c|c|c|c|}
\hline Bacterial isolate & $\begin{array}{l}\text { Identification (closest } \\
\text { GenBank sequence, } \\
\% \text { similarity) }\end{array}$ & $\begin{array}{l}\text { Response/ } \\
\text { [MC-LR] }\end{array}$ & $\mathrm{p}$ value \\
\hline \multicolumn{4}{|l|}{ BBD } \\
\hline BBD-216-1a & $\begin{array}{l}\text { Vibrio harveyi } \\
\text { (AY264926/AY911396, 99\%) }\end{array}$ & - & \\
\hline BBD-216-4a & $\begin{array}{l}\text { Methylarcula sp. } \\
\text { (AJ534208, 96\%) }\end{array}$ & $\mathrm{S} / 100 \mu \mathrm{g} \mathrm{l} \mathrm{l}^{-1}$ & $\mathrm{p}<0.02$ \\
\hline BBD-216-3d & $\begin{array}{l}\text { Bacillus megaterium } \\
\text { (AJ717381,99\%) }\end{array}$ & - & \\
\hline BBD-216-4f & $\begin{array}{l}\text { Marinobacter sp. } \\
\text { (AY196982, 99\%) }\end{array}$ & - & \\
\hline BBD-216-4g & $\begin{array}{l}\text { M. aquaeolei } \\
\text { (AJ000726, 99\%) }\end{array}$ & - & \\
\hline BBD-216-4i & $\begin{array}{l}\text { Idiomarina sp. } \\
\text { (AB167036, } 98 \%)\end{array}$ & $\mathrm{S} / 1 \mu \mathrm{g} \mathrm{l^{-1 }}$ & $\mathrm{p}<0.01$ \\
\hline BBD-217-1c & $\begin{array}{l}\text { Photobacterium } \\
\text { eurosenbergii } \\
\text { (AJ842346, 99\%) }\end{array}$ & $\mathrm{S} / 500 \mu \mathrm{g} \mathrm{l}^{-1}$ & $\mathrm{p}<0.05$ \\
\hline BBD-217-1a & $\begin{array}{l}\text { Bacillus cereus } \\
\text { (AY305275, 99\%) }\end{array}$ & - & \\
\hline BBD-217-2d & $\begin{array}{l}\text { Vibrio harveyi } \\
\text { (AY750576, 99\%) }\end{array}$ & $\mathrm{I} / 100 \mu \mathrm{g} \mathrm{l}^{-1}$ & $\mathrm{p}<0.05$ \\
\hline BBD-217-2g & $\begin{array}{l}\text { Alteromonas sp. } \\
\text { (AY626838, 99\%) }\end{array}$ & - & \\
\hline \multicolumn{4}{|l|}{ SML } \\
\hline $\mathrm{H}-1-2$ & $\begin{array}{l}\text { Alcanivorax sp. } \\
\text { (EU781516, 99\%) }\end{array}$ & $\mathrm{I} / 1 \mu \mathrm{g} \mathrm{l^{-1 }}$ & $\mathrm{p}<0.0005$ \\
\hline H-1-3 & $\begin{array}{l}\text { Vibrionaceae bacterium } \\
\text { (EF584057, 99\%) }\end{array}$ & $\mathrm{I} / 500 \mu \mathrm{g} \mathrm{l}^{-1}$ & $\mathrm{p}<0.05$ \\
\hline H-1-5 & $\begin{array}{l}\text { Vibrio harveyi } \\
\text { (DQ995248, 99\%) }\end{array}$ & - & \\
\hline $\mathrm{H}-1-7$ & $\begin{array}{l}\text { Vibrio sp. } \\
\text { (EU267643, 100\%) }\end{array}$ & $\mathrm{I} / 1 \mu \mathrm{g} \mathrm{l^{-1 }}$ & $\mathrm{p}=0.005$ \\
\hline H-1-8a & $\begin{array}{l}\text { Bacillus sp. } \\
\text { (EU070391, 99\%) }\end{array}$ & - & \\
\hline $\mathrm{H}-1-8 \mathrm{~b}$ & $\begin{array}{l}\text { Bacillus sp. } \\
\text { (FJ461465, 99\%) }\end{array}$ & $\begin{array}{c}\mathrm{I} / 1 \mu \mathrm{g} \mathrm{l}^{-1} \\
\mathrm{~S} / 500 \mu \mathrm{gl}^{-1}\end{array}$ & $\begin{array}{l}p=0.001 \\
p<0.005\end{array}$ \\
\hline H-1-9 & $\begin{array}{l}\text { Vibrio harveyi } \\
\text { (DQ995240, 98\%) }\end{array}$ & - & \\
\hline H-1-10 & $\begin{array}{l}\text { Vibrio sp. } \\
\text { (EU267643, 100\%) }\end{array}$ & - & \\
\hline $\mathrm{H}-1-11$ & $\begin{array}{l}\text { Vibrio sp. } \\
\text { (FJ178079, 97\%) }\end{array}$ & - & \\
\hline $\mathrm{H}-1-12$ & $\begin{array}{l}\text { Vibrio sp. } \\
(\text { EF100710, 98\%) }\end{array}$ & - & \\
\hline H-1-13 & $\begin{array}{l}\text { Vibrio sp. } \\
\text { (FJ457416, 99\%) }\end{array}$ & - & \\
\hline H-1-16 & $\begin{array}{l}\text { Vibrio sp. } \\
\text { (EF584084, 98\%) }\end{array}$ & $\begin{array}{c}\mathrm{I} / 1 \mu \mathrm{g} \mathrm{l}^{-1} \\
\mathrm{~S} / 100 \mu \mathrm{gl}^{-1}\end{array}$ & $\begin{array}{l}\mathrm{p}<0.005 \\
\mathrm{p}=0.0002\end{array}$ \\
\hline \multicolumn{4}{|c|}{ Known coral pathogens } \\
\hline $\begin{array}{l}\text { Aurantimonas } \\
\text { coralicida }\end{array}$ & na & - & \\
\hline Serratia marcescens & na & $\mathrm{S} / 500 \mu \mathrm{g} \mathrm{l^{-1 }}$ & $\mathrm{p}<0.05$ \\
\hline Vibrio shilonii & na & $\mathrm{S} / 1 \mu \mathrm{g} \mathrm{l}^{-1}$ & $\mathrm{p}<0.01$ \\
\hline
\end{tabular}

and SML) communities. Thus, the resident SML population may have been involved in the failure of BBD from $C$. natans to infect $M$. annularis. This is a very interesting hypothesis; however, investigation of this aspect of BBD was outside the scope of this study.

\section{Effects of disruption of oxygenic photosynthesis and sulfate reduction on BBD}

The metabolic inhibition experiments targeted 2 of the major metabolic pathways functioning within the BBD microbial consortium, oxygenic photosynthesis and dissimilatory sulfate reduction, carried out by BBD cyanobacteria and sulfate-reducing bacteria, respectively. Both pathways are tied to production of toxic substances, but in different ways. In the case of microcystin production, the connection is indirect in that microcystin synthesis is positively correlated with cyanobacterial energy production (Kaebernick \& Neilan 2001, Kaebernick et al. 2002, Codd et al. 2005), which can involve different energyyielding metabolic pathways in addition to oxygenic photosynthesis (Stal 1995). In contrast, production of sulfide by sulfate reducers is the result of sulfide being a specific byproduct of the (energy yielding) dissimilatory sulfate reduction pathway. Therefore, whereas inhibition of sulfate reduction by sodium molybdate will completely block sulfide production, inhibition of oxygenic photosynthesis by DCMU would not block microcystin formation if other energy yielding pathways are operating.

Disruption of the 2 pathways using the specific inhibitors DCMU and sodium molybdate had very different effects. Exposure of BBD inocula to sodium molybdate had a pronounced and striking effect in that it always prevented BBD infection. These results indicate that sulfide is required for the initiation of this disease. In contrast, the disruption of oxygenic photosynthesis had no effect on BBD infec- 
tion. Neither inhibitor prevented continued BBD tissue degradation when a band had formed and was actively migrating and lysing coral tissue. Together these results indicate that, although sulfide is required for BBD infection, it is not required for continued tissue lysis. Therefore, there must be other toxin(s) or toxicant(s) present for sustained tissue lysis associated with BBD pathobiology.

Microcystin, a toxin known to be present in BBD, is potentially responsible for the continued coral tissue lysis we observed when sulfate reduction was shut down. Since microcystin synthesis is linked to cyanobacterial energy production (Van der Westhuizen \& Eloff 1985, Lee et al. 2000, Vézie et al. 2002), it could be powered by different energy-yielding metabolic pathways. In other words, disruption of only one of the cyanobacterial energy yielding pathways (oxygenic photosynthesis) may not be important in BBD disease etiology due to the fact that cyanobacteria are metabolically very flexible (Stal 1995). BBD cyanobacteria may be contributing to toxin production based on multiple energy yielding pathways that could support microcystin synthesis. In our experiments, the BBD cyanobacteria in our model system, similar to natural BBD infections, were exposed to organic carbon (and high nutrients) in both the light and dark due to the fact that the BBD mat overlies lysing coral tissue. This organic carbon could be an energy source in that some cyanobacteria are capable of aerobic respiration or fermentation using exogenous organic carbon as an energy yielding pathway, and all cyanobacteria tested can use organic carbon in photoheterotrophy (Stal 1995). One cultured BBD cyanobacterium, a member of the genus Geitlerinema, has recently been shown to exhibit enhanced survival under both aerobic and anaerobic conditions in darkness when supplied with exogenous organic carbon (sugars and amino acids; Richardson \& Ragoonath 2008). A second BBD cyanobacterial isolate, a member of the genus Leptolyngbya, showed increased microcystin synthesis in the presence of fructose and glucose in the light and dark when compared to photoautotrophic controls (Gantar et al. 2009). Therefore, microcystin production could very well still occur in BBD when oxygenic photosynthesis is shut down.

Involvement of microcystin in the etiology of BBD could also play a role in the requirement of sulfide for BBD pathogenesis. Microcystin is a large hydrophilic compound and would not easily cross the epidermis of the coral host. Based on this, the role of sulfide may include, in addition to its own toxicity, the lysis of the coral epidermis, which would then allow microcystin to penetrate the gastrovascular canal. Once breached, microcystin could then lyse coral tissue in the absence of sulfide.

\section{Effect of sulfide and microcystin on coral tissue}

Exposure of healthy coral fragments to microcystin resulted in degradation of the coral tissue layers at all concentrations tested (Table 1). At $1 \mu \mathrm{g} \mathrm{l^{-1 }}$, there was also an increase in the number of bacterial cells associated with coral tissue and zooxanthellae. It is possible that the increased bacterial growth is a result of stimulation by microcystin (discussed below) which may have contributed to coral tissue degradation. At $50 \mu \mathrm{g}$ $\mathrm{l}^{-1}$ of microcystin, bacterial growth was much lower, but greater than the control. Under this experimental condition, the columnar cells in the epidermis were vaculated, and zooxanthellae were extruded from the gastrodermis, suggesting that microcystin directly degrades coral tissue. These effects were exacerbated with exposure to $100 \mu \mathrm{g} \mathrm{l}^{-1}$ microcystin, in which the epidermis appeared to be significantly thinned, or absent, leaving behind clusters of zooxanthellae.

Exposure to sulfide caused effects similar to exposure to the higher concentrations of microcystin, with severely vacuolated columnar cells and degraded gastrodermis. Zooxanthellae again appeared to clump into clusters within the gastrodermis, but appeared healthy. With exposure to sulfide it was interesting to note the appearance of filamentous cyanobacteria below the calicodermis.

The above effects were exacerbated when coral fragments were exposed to the combination of microcystin and sulfide, both in terms of the degree of the deleterious effect and length of time before the effect was observed. In these experiments, exposure to both substances led to complete degradation of the epidermal and gastrodermal layers, and these effects were apparent sooner than when the substances were used alone. The zooxanthellae in coral fragments exposed to the combination of sulfide and microcystin showed some signs of degradation, but not to the extent of the coral animal, suggesting that zooxanthellae may not suffer the same effects of BBD infection as the coral host (lysis and death). These results are supported by the fact that examination of freshly collected BBD field samples using light microscopy often reveals intact zooxanthellae in the BBD microbial mat, presumably released from the physical symbiosis when the coral tissue is lysed.

Our finding that both sulfide and microcystin have toxic effects on coral tissue and zooxanthellae is not surprising considering the fact that the 2 substances act differently on target cells. Sulfide is toxic in that it poisons both respiratory and photosynthetic electron transport (Vismann 1991). Microcystin is toxic because it inhibits protein synthesis, protein and nuclear protein phosphatases, disrupts membrane integrity and conduction, and can induce apoptosis (MacKintosh et 
al. 1990, Sim \& Mudge 1993, Hooser 2000). Thus, while microcystin may target both the zooxanthellae and coral animal by the same toxic mechanisms affecting overall cellular metabolism, zooxanthellae would be further affected by disruption of photosynthesis (along with respiration) by sulfide.

There may be an additional way in which the 2 compounds interact. The requirement for sulfide production for the initiation of BBD when an infective piece of BBD mat is placed on the surface of healthy coral may be because sulfide exposure, which is known to cause coral tissue lysis (Richardson et al. 1997), is necessary to allow microcystin to penetrate coral cells and tissues. Structurally, microcystin is a cyclic heptapeptide and, being hydrophilic, would not easily penetrate intact coral tissue (Codd et al. 2005). This could be the basis for the finding of other investigators (Aeby \& Santavy 2006) that BBD infection requires that the coral surface be wounded for infection to occur.

\section{Effect of microcystin on bacterial growth}

Based on the observations of a pronounced increase in the number of bacteria present in the gastrodermis of corals exposed to microcystin at $1 \mu \mathrm{g} \mathrm{l}^{-1}$, and relatively (to the control) more bacteria at higher concentrations, we assessed the effect of exposure of bacterial cultures to this compound. While only a limited number of cultures were tested, we did find a pattern in which BBD bacterial isolates appeared to be, in general, stimulated by microcystin (3 of 10 isolates stimulated, 1 isolate inhibited) while SML bacteria were more often inhibited (3 of 12 isolates). Two of the SML isolates were inhibited at the lowest concentration of microcystin but stimulated at the highest concentration. Thus, there may be a role of microcystin, besides its toxicity, in the pathobiology of BBD by structuring the BBD microbial community. It is known that some bacteria can grow on microcystin as a carbon and energy source (Park et al. 2001, Eleuterio \& Batista 2005). The known production of microcystin by BBD cyanobacteria (Richardson et al. 2007) may, in addition to contributing directly to coral tissue lysis and death, have an etiological role in selecting for BBD microorganisms and against potentially protective members of the coral SML that might prevent BBD infection.

As discussed above, very little is known about the relationship between the bacterial communities in the SML and BBD. It may be that once a coral is infected with BBD, certain SML bacteria from the infected coral host could be incorporated into the BBD consortium. Such bacteria would benefit from the high nutrient/enriched organic carbon of the lysing coral tissue. However, such bacteria would have to be resis- tant to sulfide, microcystin, and the dramatic ranges of oxygen (anoxia to supersaturated), $\mathrm{pH}$, and redox potential that occur inside the band environment (Carlton \& Richardson 1995). These aspects of BBD are completely unexplored.

\section{Additional potential toxins in BBD}

The experiments described in this study do not rule out the presence of additional toxins operating in BBD. To date, only 3 of potentially many cyanotoxins have been investigated in BBD. While we did find the hepatotoxin microcystin in BBD, 2 other cyanobacterial toxins, saxitoxin and anatoxin-a (both neurotoxins), were not detected in BBD field samples or cultures of BBD cyanobacteria using analytical techniques (Richardson et al. 2007). Many more cyanotoxins have not, to our knowledge, been the subject of study in BBD research. As mentioned previously, sequences homologous to bacteria associated with toxin-producing dinoflagellates are common in BBD (discussed in detail by Sekar et al. 2008). Again, to our knowledge, no one has investigated the potential role of these toxins in BBD.

In summary, our work has shown that at least 2 toxic compounds, sulfide and microcystin, are present in $\mathrm{BBD}$ and that they deleteriously affect both the coral animal and associated zooxanthellae. We have also shown that, in the case of the coral animal, these 2 substances act synergistically. Finally, we have presented preliminary results indicating that one of these substances, microcystin, has both positive and negative effects on growth of coral- and BBD-associated bacteria and therefore may have a role in structuring the complex BBD microbial community.

Acknowledgements. We thank J. D. Voss and E. Remily for assistance in the field, K. Rein for providing purified microcystin, P. Blackwelder, H. Al Sayegh, and A. Renegar for assistance with SEM, and G. M. King for providing customized experimental chambers. The insightful comments of 2 anonymous reviewers improved this manuscript. This research was supported by NIH (NIH/NIGMS SO6GM8205), and NOAA's Caribbean Marine Research Center (CMRC-04PRJV-01-04C). This is contribution 167 of the Tropical Biology Program at Florida International University.

\section{LITERATURE CITED}

Aeby GS, Santavy DL (2006) Factors affecting susceptibility of the coral Montastraea faveolata to black-band disease. Mar Ecol Prog Ser 318:103-110

Antonius A (1973) New observations on coral destruction in reefs. 10th Mtg Assoc Isl Mar Lab Caribb 10:3

Antonius A (1985) Coral diseases in the Indo-Pacific: a first record. PSZN I: Mar Ecol 6:197-218

Antonius A (1988) Distribution and dynamics of coral diseases 
in the eastern Red Sea. Proc 6th Int Coral Reef Symp 3:145-150

Banin E, Khare SK, Naider F, Rosenberg E (2001) Proline-rich peptide from the coral pathogen Vibrio shiloi that inhibits photosynthesis of zooxanthellae. Appl Environ Microbiol 67:1536-1541

Barash Y, Sulam R, Loya Y, Rosenberg E (2005) Bacterial strain BA-3 and a filterable factor cause a white plaguelike disease in corals from the Eilat coral reef. Aquat Microb Ecol 40:183-189

Bruckner A, Bruckner R (1997) The persistence of black band disease in Jamaica: impact on community structure. Proc 8th Int Coral Reef Symp 1:601-606

> Carlton R, Richardson L (1995) Oxygen and sulfide dynamics in a horizontally migrating cyanobacterial mat: black band disease of corals. FEMS Microbiol Ecol 18:155-162

Codd GA, Lindsay J, Young FM, Morrison LF, Metcalf JS (2005) Cyanobacterial toxins. In: Huisman J, Matthijs HCP, Visser PM (eds) Harmful cyanobacteria. Springer, Dordrecht, $\mathrm{p}$ 1-23

> Cooney R, Pantos O, Le Tissier M, Barer M, O'Donnell A, Bythell J (2002) Characterization of the bacterial consortium associated with black band disease in coral using molecular microbiological techniques. Environ Microbiol 4:401-413

Dinsdale E (2002) Abundance of black band disease on corals from one location on the Great Barrier Reef: a comparison with abundance in the Caribbean region. Proc 9th Int Coral Reef Symp 2:1239-1244

> Ducklow H, Mitchell R (1979) Observations on naturally and artificially diseased tropical corals: a scanning electron microscope study. Microb Ecol 5:215-223

Edmunds PJ (1991) Extent and effect of black band disease on Caribbean reefs. Coral Reefs 10:161-165

Eleuterio L, Batista JR (2005) Removal of the cyanobacterial toxin microcystin-LR by biofiltration. Int Symp Cyanobacterial Harmful Algal Blooms (ISOC-HAB), Durham, NC (Abstract)

> Frias-Lopez J, Klaus JS, Bonheyo GT, Fouke BW (2004) Bacterial community associated with black band disease in corals. Appl Environ Microbiol 70:5955-5962

Gantar M, Sekar R, Richardson LL (2009) Cyanotoxins from black band disease of corals and from other coral reef environments. Microb Ecol (in press) doi:10.1007/s00248009-9540

> Garrett P, Ducklow H (1975) Coral disease in Bermuda. Nature 253:349-350

Hooser SB (2000) Fulminant hepatocyte apoptosis in vivo following microcystin LR administration to rats. Toxicol Pathol 28:726-733

Kaczmarsky LT, Draud M, Williams EH (2005) Is there a relationship between proximity to sewage effluent and the prevalence of coral disease? Caribb J Sci 41:124-137

Kaebernick M, Neilan B (2001) Ecological and molecular investigation of cyanotoxin production. FEMS Microbiol Ecol 35:1-9

Kaebernick M, Dittmann E, Borner T, Neilan BA (2002) Multiple alternate transcripts direct the biosynthesis of microcystin, a cyanobacterial. Appl Environ Microbiol 68:4 49-455

Kuta KG, Richardson L (1996) Abundance and distribution of black band disease of corals in the northern Florida Keys. Coral Reefs 15:219-223

Kuta KG, Richardson LL (2002) Ecological aspects of black band disease of corals: relationships between disease incidence and environmental factors. Coral Reefs 21:393-398

Lee SJ, Jang MH, Kim HS, Yoon BD, Oh HM (2000) Variation of microcystin content of Microcystis aeruginosa relative to medium N:P ration and growth stage. Appl Environ Microbiol 89:323-329

MacKintosh C, Beattie K, Klumpp S, Cohen P, Codd G (1990) Cyanobacterial microcystin-LR is a potent and specific inhibitor of protein phosphatases 1 and 2A from both mammals and higher plants. FEBS Lett 264:187-192

> Myers JL, Sekar R, Richardson L (2007) Molecular detection and ecological significance of the cyanobacteria Geitlerinema and Leptolyngbya in black band disease of corals. Appl Environ Microbiol 73:5173-5182

Park HD, Sasaki Y, Maruyama T, Yanagisawa E, Hiraishi A, Kato K (2001) Degradation of the cyanobacterial microcystin by a new bacterium isolated from a hypertrophic lake. Environ Toxicol 16:337-343

Richardson LL (2004) Black band disease. In: Rosenberg E, Loya Y (eds) Coral health and disease. Springer-Verlag, Berlin, p 325-336

Richardson LL, Ragoonath D (2008) Organic carbon enhances dark survival of the cyanobacterium Geitlerinema sp. isolated from black band disease of corals. Rev Biol Trop 56:119-126

Richardson L, Kuta K, Schnell S, Carlton R (1997) Ecology of the black band disease microbial consortium. Proc 8th Int Coral Reef Symp 1:597-600

> Richardson LL, Sekar R, Myers JL, Gantar M and others (2007) The presence of the cyanobacterial toxin microcystin in black band disease of corals. FEMS Microbiol Ecol 272:182-187

> Rodriguez S, Croquer A (2008) Dynamics of black band disease in a Diploria strigosa population subjected to annual upwelling on the northeastern coast of Venezuela. Coral Reefs 27:381-388

Rohwer F, Segritan V, Azam F, Knowlton N (2002) Diversity and distribution of coral-associated bacteria. Mar Ecol Prog Ser 243:1-10

> Rützler K, Santavy D (1983) The black band disease of Atlantic reef corals. I. Description of the cyanophyte pathogen. PSZN I: Mar Ecol 4:301-319

Rützler K, Santavy D, Antonius A (1983) The black band disease of Atlantic reef corals. III. Distribution, ecology and development. PSZN I: Mar Ecol 4:329-358

Sekar R, Mills D, Remily E, Voss J, Richardson L (2006) Microbial communities in the surface mucopolysaccharide layer and the black band microbial mat of black band diseased Siderastrea siderea. Appl Environ Microbiol 72: 5963-5973

Sekar R, Kaczmarsky LT, Richardson LL (2008) Microbial community composition of black band disease on the coral host Siderastrea siderea from three regions of the wider Caribbean. Mar Ecol Prog Ser 362:85-98

Sim ATR, Mudge LM (1993) Protein phosphatase activity in cyanobacteria - consequences for microcystin toxicity analysis. Toxicon 31:1179-1186

Stal JJ (1995) Physiological ecology of cyanobacteria in microbial mats and other communities. New Phytol 131:1-32

$>$ Van der Westhuizen AK, Eloff JN (1985) Effects of temperature and light on toxicity and growth of the blue-green alga Microcystis aeruginosa [UV-006]. Planta 163:55-59

Vézie C, Rapala J, Vaitomaa J, Seitsonen J, Sivonen K (2002) Effect of nitrogen and phosphorus on growth of toxic and nontoxic Microcystis strains and on intracellular microcystin. Microb Ecol 43:443-454

Vismann B (1991) Sulfide tolerance: physiological mechanisms and ecological implications. Ophelia 34:1-27

> Voss JD, Mills DK, Myers JL, Remily ER, Richardson LL (2007) Black band disease microbial community variation on corals in three regions of the wider Caribbean. Microb Ecol 54:730-739 